\title{
Antibacterial activity against $\beta$ - lactamase producing Methicillin and Ampicillin-resistants Staphylococcus aureus: fractional Inhibitory Concentration Index (FICl) determination
}

\author{
Kiessoun Konaté ${ }^{1,5^{*}}$, Jacques François Mavoungou ${ }^{2}$, Alexis Nicaise Lepengué ${ }^{3}$, Raïssa RR Aworet-Samseny ${ }^{4}$, \\ Adama Hilou', Alain Souza ${ }^{5}$, Mamoudou H Dicko ${ }^{6}$ and Bertrand M'Batchi ${ }^{3}$
}

\begin{abstract}
Background: The present study reports the antibacterial capacity of alkaloid compounds in combination with Methicillin and Ampicillin-resistants bacteria isolated from clinical samples. The resistance of different bacteria strains to the current antibacterial agents, their toxicity and the cost of the treatment have led to the development of natural products against the bacteria resistant infections when applied in combination with conventional antimicrobial drugs.
\end{abstract}

Method: The antibacterial assays in this study were performed by using inhibition zone diameters, MIC, MBC methods, the time-kill assay and the Fractional Inhibitory Concentration Index (FICI) determination. On the whole, fifteen Gram-positive bacterial strains (MRSA/ARSA) were used. Negative control was prepared using discs impregnated with $10 \%$ DMSO in water and commercially available Methicillin and Ampicillin from Alkom Laboratories LTD were used as positive reference standards for all bacterial strains.

Results: We noticed that the highest activities were founded with the combination of alkaloid compounds and conventional antibiotics against all bacteria strains. Then, results showed that after $7 \mathrm{~h}$ exposition there was no viable microorganism in the initial inoculums.

Conclusion: The results of this study showed that alkaloid compounds in combination with conventional antibiotics (Methicillin, Ampicillin) exhibited antimicrobial effects against microorganisms tested. These results validate the ethno-botanical use of Cienfuegosia digitata Cav. (Malvaceae) in Burkina Faso. Moreover, this study demonstrates the potential of this herbaceous as a source of antibacterial agent that could be effectively used for future health care purposes.

\section{Background}

Infectious diseases constitute the leading cause of premature deaths in the world and kill almost 50,000 people every day. An increase in antibiotic resistant bacteria is threatening world population with the recurrence of infectious diseases that were once thought to be under

\footnotetext{
* Correspondence: mehekiessoum@yahoo.fr

'Laboratoire de Biochimie et Chimie Appliquées (LABIOCA), UFR/SVT, Université de Ouagadougou, Ouagadougou 0909 BP 848, Burkina Faso ${ }^{5}$ Laboratoire de Physiologie Animale, Electrophysiologie et de Pharmacologie, Faculté des Sciences, Université des Sciences et Techniques de Masuku, Franceville, Gabon

Full list of author information is available at the end of the article
}

control at least in developed countries. In the recent years incidence of multi-drug resistance in Gram-positive, Gram-negative and other bacteria like Mycobacterium tuberculosis has been reported from all over the world [1]. These multi-drug resistant bacteria have also created additional problems in cancer and AIDS patients.

Methicillin resistant Staphylococcus aureus (MRSA) has gained much attention in the last decade, as the MRSA is a major cause of hospital acquired (nosoconical infections) $\beta$-lactam antibiotics are the preferred drugs against Staphylococcus aureus infections. S.aureus has developed resistance to the $\beta$-lactam antibiotics due to

\section{Ciomed Central}


the production of chromosomal or plasmid mediated $\beta$ lactamases [2]. Moreover, increase incidence of vancomycinresistant has also been reported [3]. Thus, the number of effective exogenous antibiotics is decreasing; therefore concerted efforts are to be made to identify antimicrobial materials from natural products and traditional medicines.

In effect, different extracts from traditional medicinal plants have been tested to identify the sources of the therapeutics effect [4]. Over the past 20 years, there has been an increased interest in the development of resistance of pathogens against antibiotics caused by the indiscriminate use of modern antibiotics [5,6]. As a result some natural products have been approved as new antibacterial drugs but there is still an urgent need to identify novel substances that are active towards pathogens with high resistance [7]. Considering the high cost of the synthetic drugs and their side effects, wide varieties of natural plants can be considered as a vital source for anti-microbial agents [8].

Therefore, the need of new and effective antimicrobial agents with broad-spectrum of activity from natural sources is increasing day by day [9]. In spite of the great advances observed in modern medicine therefore, plants still make an important contribution to health care. This is due in part to the recognition of the value of traditional medical systems and the identification of medicinal plants from indigenous pharmacopoeias which have significant healing power [10]. In addition, natural plant products, accordingly provide a contimal inspiration of bioactive antimicrobial agents

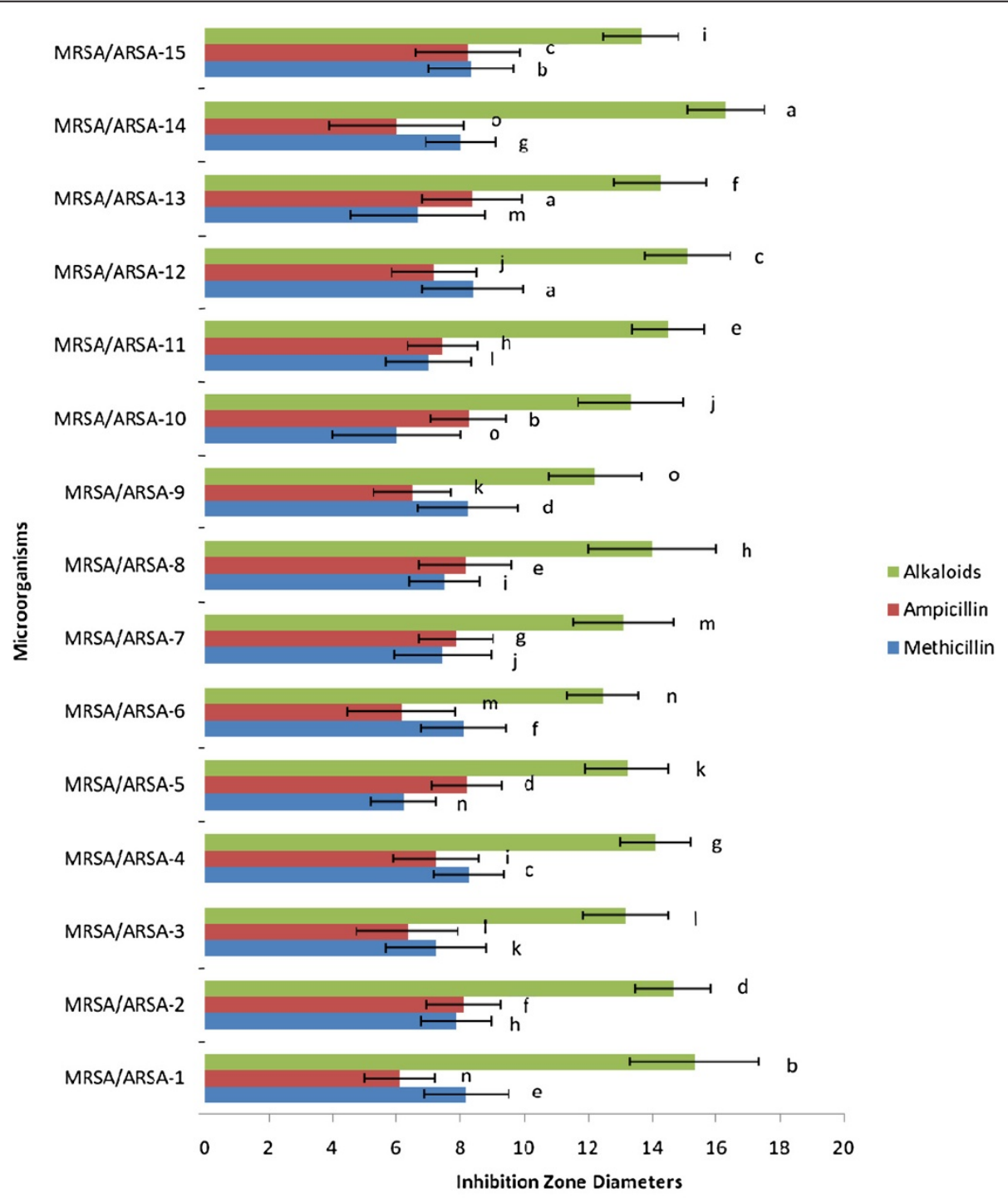

Figure 1 Inhibition Zone Diameters of Alkaloid compounds from Cienfuegosia digitata Cav. and conventional antibiotics (Methicillin and Ampicillin). The results are the means of number of the colonies \pm standard deviations. 
with low toxicity, a broad spectrum and good pharmacokinetics to be clinically used without chemical modification [11]. So, such plants should be investigated to better understand their therapeutic properties, safety and efficiency [12].

Herbal medicine has become an ideal remedy for treatment of the diseases due to lesser amount of side effects, better compatibility and only accessible treatment for some diseases [13]. In the continuous search for active phytochemicals against pathogenic infectious Cienfuegosia digitata Cav. (Malvaceae) an herbaceous, has received considerable attention. This plant is a savannah herbaceous belonging to the family of Malvaceae and is abundantly distributed in the central and north of in Burkina Faso. Medicinally, it is used to heal the infectious wounds, to cure the cough, throat complaints, dysentery and others infectious diseases in children: diarrhoea, acute colitis, malaria, fever, pain, variola. In addition, this plant has antibacterial, anti-inflammatory, analgesic and hepatoprotective properties [14]. In previous study, the aqueous acetone extract from this herbaceous was evaluated for its antioxidant and anti-inflammatory activities [15] due to its composition in saponosides, coumarins, steroids, polyphenol, alkaloid compounds [14]. However, no systematic study has been reported concerning antibacterial activity of aqueous acetone extract of Cienfuegosia digitata Cav. This plant has not exhaustively been screened for antimicrobial activity.

Hence, the present study was conducted to study out the antibacterial of alkaloid compounds from Cienfuegosia digitata Cav., against the locally isolated microorganisms from patients having infectious diseases. The

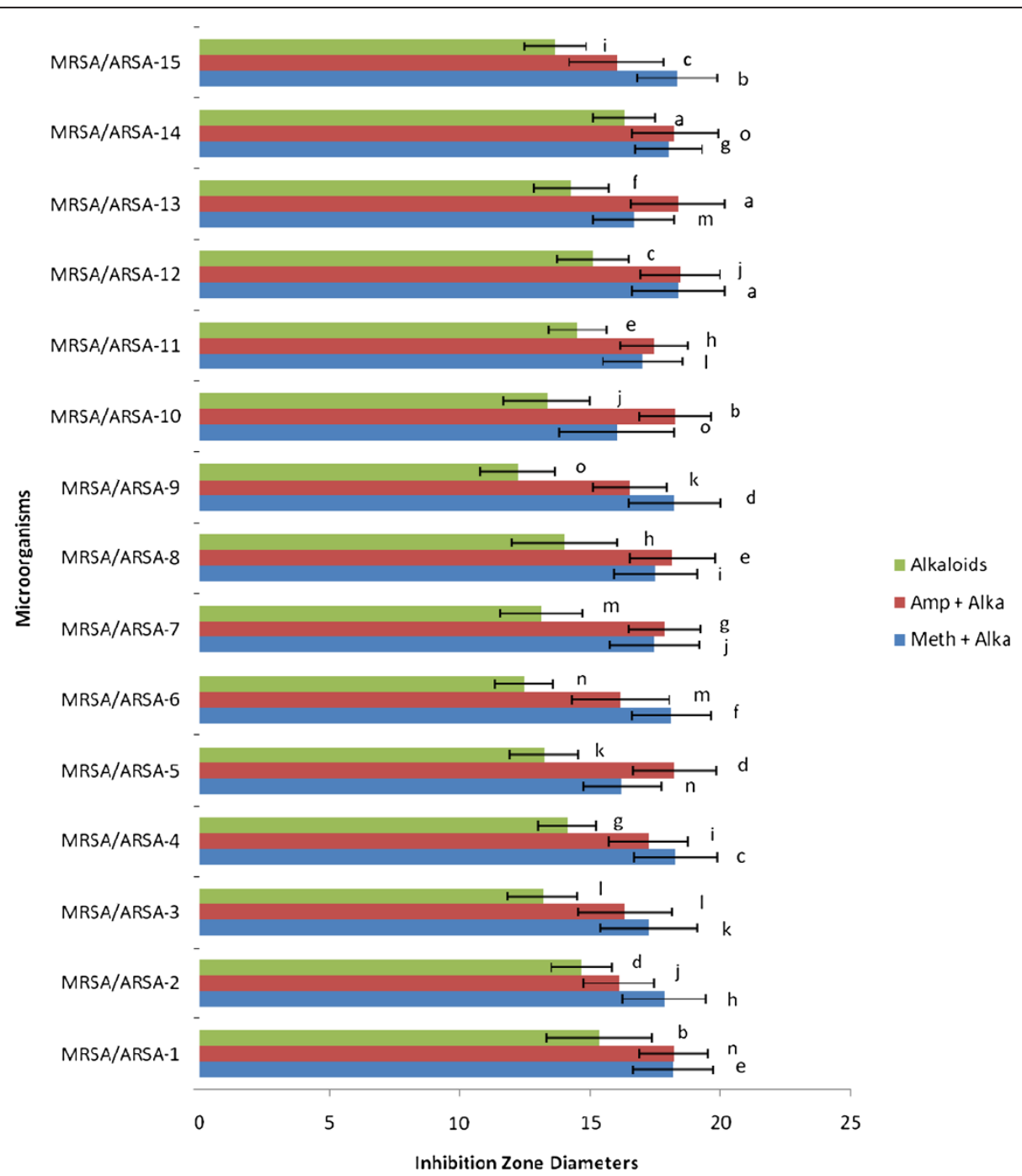

Figure 2 Inhibition Zone Diameters of Alkaloid compounds and their combination with conventional antibiotics (Methicillin and Ampicillin). Amp= Ampicillin; Meth= Methicillin; Alk= Alkaloids. The results are the means of number of the colonies \pm standard deviations. 
bacteriostatic, bactericidal, time-kill assay and Fractional Inhibitory Concentration Index studies of the alkaloid compounds were screened against clinical strains of bacteria with an aim of manufacturing some drugs like alkaloid compounds or a combination with conventional antimicrobial drugs to better manage resistant bacteria infectious diseases.

\section{Materials}

\section{Plant materials}

Cienfuegosia digitata Cav. (Malvaceae) was freshly collected in August 2008 in Gampela, $25 \mathrm{Km}$ east of Ouagadougou, capital of Burkina Faso. The plant was botanically identified by Prof. Millogo-Rasolodimby from the plant Biology Department of the University of Ouagadougou. Voucher specimen (ID-10472) was deposited at the
Herbarium of the "Laboratoire de Biologie et d'Ecologie Végétale, UFR/SVT of University of Ouagadougou".

\section{Bacterial strains and antibiotics}

Microorganisms used in this study were isolated from clinical samples at Laboratory of the General Hospital of Ouagadougou in Burkina Faso. Methicillin $(25 \mu \mathrm{g})$ and Ampicillin $(25 \mu \mathrm{g})$ were purchased from Alkom Laboratories LTD. Clinical isolates were: MRSA/ARSA-1, MRSA/ARSA-2, MRSA/ARSA-3, MRSA/ARSA-4, MRSA/ ARSA-5, MRSA/ARSA-6, MRSA/ARSA-7, MRSA/ARSA-8, MRSA/ARSA-9, MRSA/ARSA-10, MRSA/ARSA-11, MRSA/ ARSA-12, MRSA/ARSA-13, MRSA/ARSA-14 and MRSA/ ARSA-15. The following microorganisms all identified by the use of their biochemical profiles as recommended by the manual "Bactériologie Medical" [16].

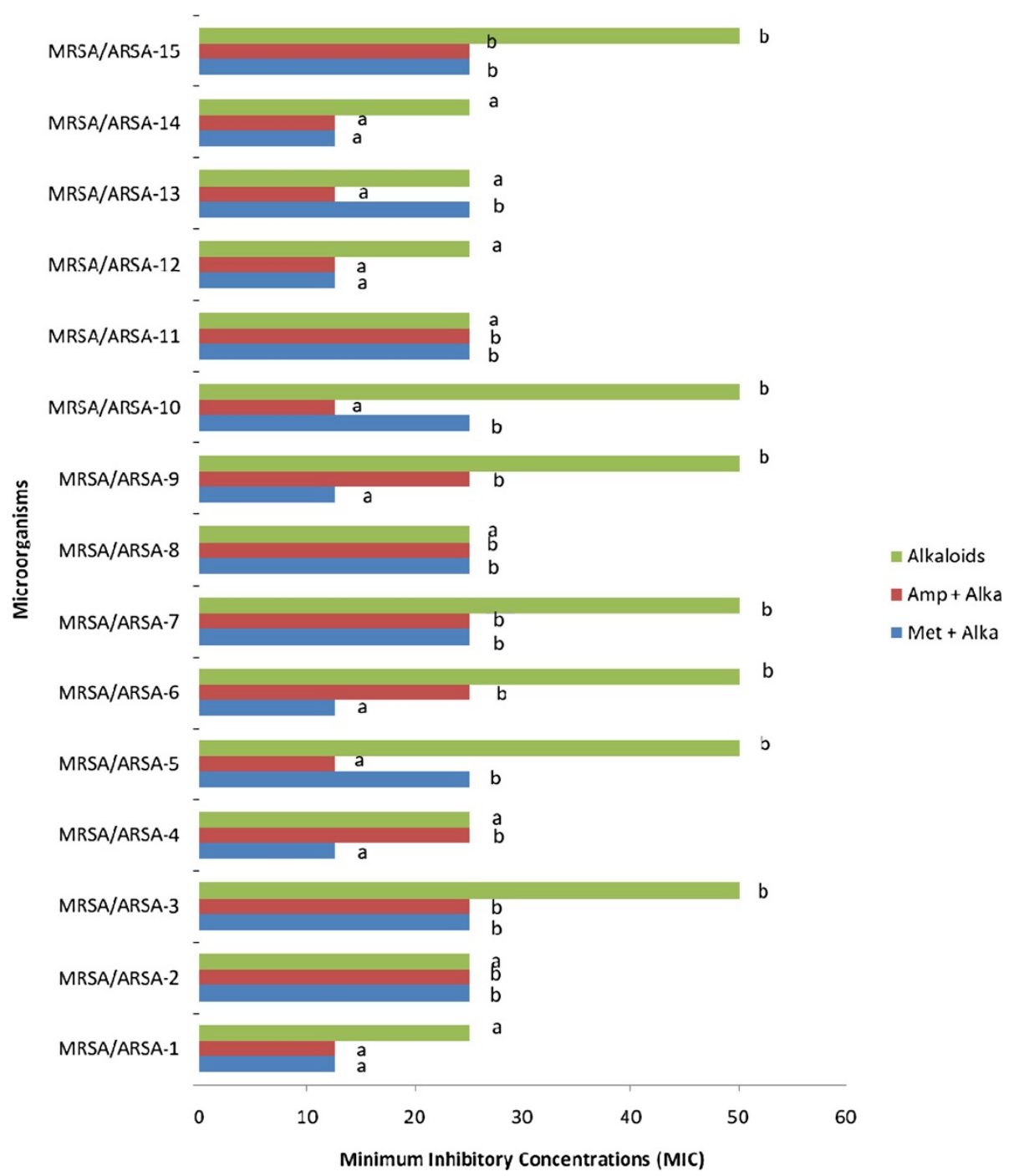

Figure 3 Minimum Inhibitory Concentration (MIC) of alkaloid compounds from Cienfuegosia digitata Cav. and their combination with Methicillin and with Ampicillin. The results are the means of number of the colonies \pm standard deviations. 


\section{Chemicals}

All reagents were of analytical grade. Acetone, n-hexane were supplied by Fluka chemie (Buchs, Switzerland). INT (p-iodonitrotetrazolium chloride) was purchased from sigma-Aldrich chemie (Steinheim, Germany).

\section{Methods}

\section{Preparation of alkaloid compounds}

The harvested plant materials fresh (broken into leaf stems) were dried in the laboratory at room temperature $\left(20-25{ }^{\circ} \mathrm{C}\right)$, afterwards samples were ground and made alkaline and $50 \mathrm{~g}$ were used with $28 \%$ ammonia and extracted with chloroform at room temperature for a total period of $24 \mathrm{~h}$ and then the extract was partitioned between $5 \% \mathrm{HCl}$ and Chloroform. The aqueous phase was made alkaline again with ammonia and partitioned between water and chloroform. Finally chloroform was totally evaporated from the organic phase to form the alkaloids powder [17].

\section{In vitro antibacterial activity Preparation of inocula}

The susceptibility tests were performed by Mueller Hinton agar-well diffusion method [18]. The bacterial strains grown on nutrient agar at $37{ }^{\circ} \mathrm{C}$ for $18 \mathrm{~h}$ were suspended in a saline solution $(0.9 \%, \mathrm{w} / \mathrm{v}) \mathrm{NaCl}$ and adjusted to a turbidity of 0.5 Mac Farland standard $\left(10^{8} \mathrm{CFU} / \mathrm{ml}\right)$. To obtain the inocula, these suspensions were diluted 100 times in Muller Hinton broth to give $10^{6}$ colony forming units (CFU)/ml [19].

\section{Preparation of discs}

The stock solutions of alkaloid compounds from Cienfuegosia digitata Cav. (Malvaceae) was dissolved in $10 \%$ dimethylsulfoxide (DMSO) in water [20] at a final concentration of $400 \mu \mathrm{g} / \mathrm{ml}$. The stock solution of alkaloid compounds from Cienfuegosia digitata Cav. (Malvaceae) was sterilized by filtration through $0.22 \mu \mathrm{m}$ sterilizing Millipore express filter. The sterile discs $(6 \mathrm{~mm})$ were

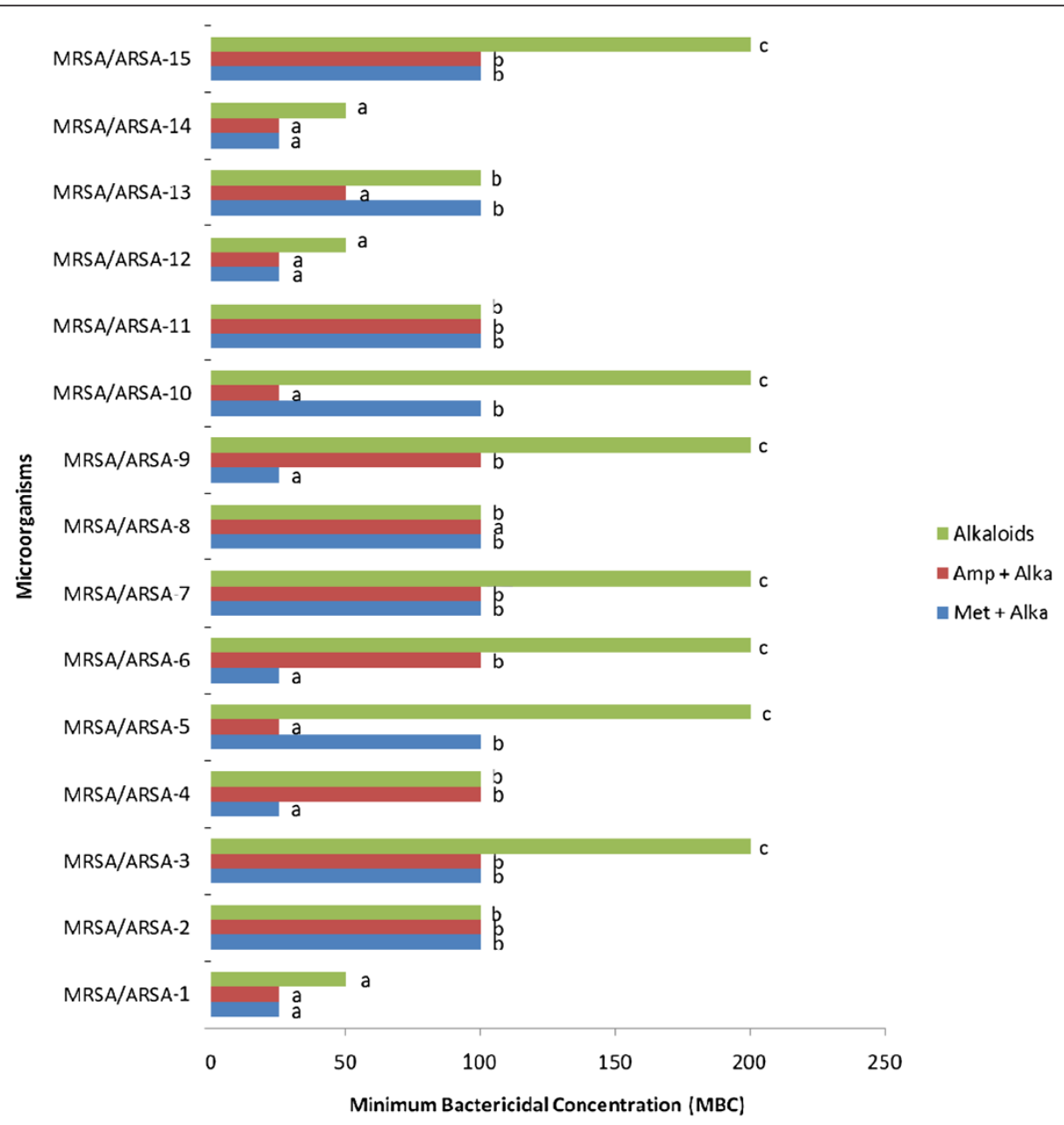

Figure 4 Minimum bactericidal Concentration (MBC) of alkaloid compounds from Cienfuegosia digitata Cav. and their combination with Methicillin and with Ampicillin. The results are the means of number of the colonies \pm standard deviations. 
impregnated with $10 \mu \mathrm{L}$ of the sterile alkaloid compounds from Cienfuegosia digitata Cav. Negative controls were prepared using discs impregnated with $10 \%$ DMSO in water and commercially available antibiotic diffusion discs (Methicillin $25 \mu \mathrm{g}$ and Ampicillin $25 \mu \mathrm{g}$ from Alkom Laboratories LTD) were used as positive reference standards for all bacterial strains.

\section{Disc-diffusion assay}

Petri plates $(9 \mathrm{~cm})$ were prepared with $20 \mathrm{ml}$ of a base layer of molten Mueller Hinton agar (DIFCO, Becton Dickinson, USA). Each Petri plate was inoculated with 15 $\mu \mathrm{l}$ of each bacterial suspension $\left(10^{6} \mathrm{CFU} / \mathrm{ml}\right)$. After drying in a sterile hood, $6 \mathrm{~mm}$ diameter discs soaked with $10 \mu \mathrm{l}$ of the different alkaloid compounds from Cienfuegosia digitata Cav. (Malvaceae) dilutions were placed on the agar. Discs containing Methicillin $(25 \mu \mathrm{g})$ and Ampicillin $(25 \mu \mathrm{g})$ were used as positive controls and $10 \%$ DMSO was used as a negative control. The plates were incubated for $24 \mathrm{~h}$ at $37^{\circ} \mathrm{C}$. The diameters of the inhibition zones were evaluated in millimeters. The extract inducing inhibition zone $\geq 3 \mathrm{~mm}$ around disc were considered as antibacterial. All tests were performed in triplicate and the bacterial activity was expressed as the mean of inhibition diameters $(\mathrm{mm})$ produced [21].

\section{Micro-well dilution assay}

Minimum inhibitory concentration (MIC) was determined by the microdilution method in culture broth as recommended previously [22]. Eight serial two-fold dilutions of alkaloid compounds or conventional antibiotics were prepared as described before, to obtain final concentration range of 400 to $3.125 \mu \mathrm{g} / \mathrm{ml}$. The 96-well micro-plates (NUNC, Danemark) containing $100 \mu \mathrm{L}$ of Mueller Hinton $(\mathrm{MH})$ broth were used. For each bacteria strain, three columns of eight wells to the microplate were used. Each well has getting: the culture medium + alkaloid compounds or Methicillin or Ampicillin or the combination of alkaloid compounds with Methicillin or Ampicillin + inoculum (10 $\mu \mathrm{l}$ of inocula) and INT $(50 \mu \mathrm{l} ; 0.2 \mathrm{mg} / \mathrm{ml})$. The plates were covered and incubated at $37{ }^{\circ} \mathrm{C}$ for $24 \mathrm{~h}$. All tests were performed in triplicate and the bacterial activity was expressed as the mean of inhibitions produced. Inhibition of bacterial growth was judged by rose or yellow colour. The MIC was defined as the lowest concentration of the alkaloid compound rich-fractions at which no colony was observed after incubation. So, the MIC was defined as the lowest concentration at which no visible growth was observed.

\section{Minimal bactericidal concentration (MBC)}

Minimum bactericidal concentration (MBC) was recorded as a lowest extract concentration killing $99.9 \%$ of the bacterial inocula after $24 \mathrm{~h}$ incubation at $37{ }^{\circ} \mathrm{C}$. Each experiment was repeated at least three times. MBC values were determined by removing $100 \mu \mathrm{l}$ of bacterial suspension from subculture demonstrating no visible growth and inoculating nutrient agar plates. Plates were incubated at $37{ }^{\circ} \mathrm{C}$ for a total period of $24 \mathrm{~h}$. The $\mathrm{MBC}$ is determined with the wells whose the concentrations are $\geq$ MIC $[21,23]$.

Table 1 Bacteriostatic (-) and Bactericidal (+) effects of Alkaloid compounds from Cienfuegosia digitata Cav. and their combination with Methicillin and with Ampicillin

\begin{tabular}{|c|c|c|c|}
\hline Microorganisms & Meth + Alkaloids & Amp + Alkaloids & Alkaloid Fractions \\
\hline MRSA/ARSA-01 & + & + & + \\
\hline MRSA/ARSA-02 & - & - & - \\
\hline MRSA/ARSA-03 & - & - & - \\
\hline MRSA/ARSA-04 & + & - & - \\
\hline MRSA/ARSA-05 & - & + & - \\
\hline MRSA/ARSA-06 & + & - & - \\
\hline MRSA/ARSA-07 & - & - & - \\
\hline MRSA/ARSA-08 & - & - & - \\
\hline MRSA/ARSA-09 & + & - & - \\
\hline MRSA/ARSA-10 & - & + & - \\
\hline MRSA/ARSA-11 & - & - & - \\
\hline MRSA/ARSA-12 & + & + & + \\
\hline MRSA/ARSA-13 & - & - & - \\
\hline MRSA/ARSA-14 & + & + & + \\
\hline MRSA/ARSA-15 & - & - & - \\
\hline
\end{tabular}

The results are the means of number of the colonies \pm standard deviations.

+: bactericidal effect (MBC/MIC $=1$ or 2$)$-: bacteriostatic effect $(M B C / M I C=4$ or 16$)$. 


\section{Evaluation of bactericidal and bacteriostatic capacity}

The action of an antibacterial on the bacterial strains can be characterized with two parameters such as Minimum inhibitory concentration (MIC) and Minimum bactericidal concentration $(\mathrm{MBC})$. According to the ratio $\mathrm{MBC} / \mathrm{MIC}$, we appreciated antibacterial activity. If the ratio $\mathrm{MBC} / \mathrm{MIC}=1$ or 2 , the effect was considered as bactericidal but if the ratio $\mathrm{MBC} / \mathrm{MIC}=4$ or 16 , the effect was defined as bacteriostatic [24].

\section{Time-kill assay}

A bactericidal effect is defined as a 3 Log decrease in the $\mathrm{CFU} / \mathrm{ml}$ or a $99.9 \%$ kill over a specified time [25]. The definition of kill for this study has been used as per [20]. Kill-time can be determined at 6 h [26]. A $90 \%$ kill at 6 $\mathrm{h}$ is equivalent to a $99.9 \%$ kill at $24 \mathrm{~h}$ [27]. In this study the kill measurement was determined by the actual reduction in viable counts at $6 \mathrm{~h}$ for each isolate. Bacteria strains possessing the bactericidal effect were chosen to perform time-kill assay. Thus, 0.5 Mac Farland standards suspensions of microorganisms were diluted to have 50 $\mathrm{ml}$ of approximately $10^{6} \mathrm{CFU} / \mathrm{ml}$ in nutriment broth, and the concentration corresponding to the best MIC, were respectively added to the corresponding culture. The cultures were incubated at $37{ }^{\circ} \mathrm{C}$. At $0,1,2,3,4,5$ and $6 \mathrm{~h}$, an aliquot of $100 \mu \mathrm{l}$ was removed and diluted with $10 \mathrm{ml}$ sterile broth. The obtained suspension was used to inoculate $9 \mathrm{~cm}$ diameter Petri plates with a sterile non toxic cotton swab on a wooden applicator as indicated before in the agar-well diffusion assay. After 24 $\mathrm{h}$ incubation at $37{ }^{\circ} \mathrm{C}$, the viability of microorganisms was evaluated by the presence of colonies on the plates and the experiment was carried out twice.

\section{Evaluation of the fractional inhibitory concentration index} of alkaloid extracts

The Muller Hinton agar dilution method was used to evaluate the Fractional Inhibitory Concentration Index

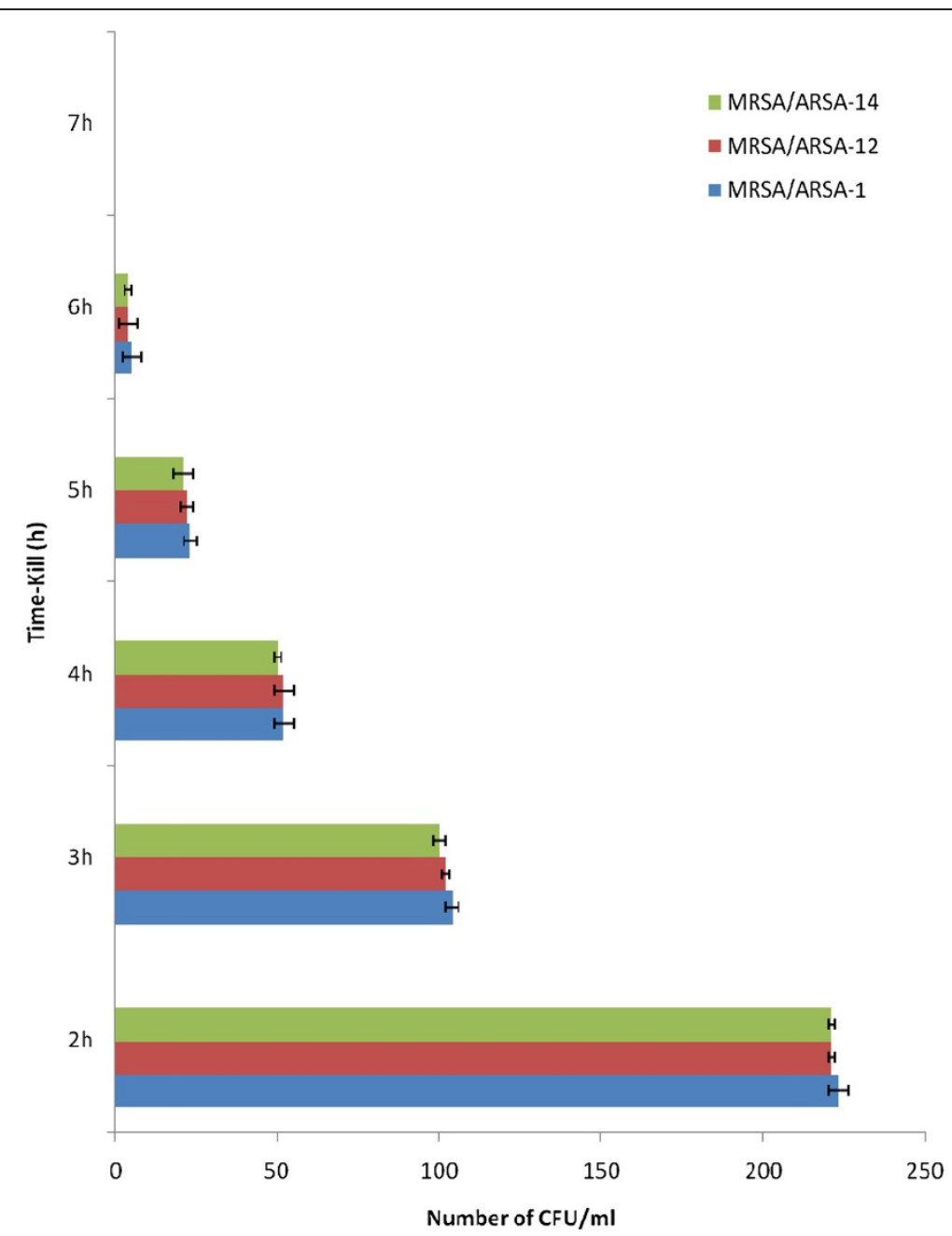

Figure 5 Viability of microorganisms after 6 hours exposure with Alkaloid compounds from Cienfuegosia digitata Cav. Absence of colonies after $6 \mathrm{~h}$. CFU uncountable before $2 \mathrm{~h}$. The results are the means of number of the colonies \pm standard deviations. 
(FICI) of alkaloid compounds from Cienfuegosia digitata Cav. (Malvaceae) and the tested anti-microbial standards as reported earlier [28,29]. Eight serial two-fold dilutions of alkaloid compounds were prepared as described before, to obtain final concentration range of 400 to $3.125 \mu \mathrm{g} / \mathrm{ml}$. A series of two-fold serial dilutions of Methicillin or Ampicillin was also prepared in the same conditions as alkaloid compounds. In this way, all antibacterial standards dilutions were mixed with the appropriate concentration of alkaloid compounds thus obtaining a series of the combinations of conventional antibiotics and alkaloid compounds. The concentrations prepared corresponded to 1 ; $1 / 2 ; 1 / 4 ; 1 / 8 ; 1 / 16 ; 1 / 32 ; 1 / 64 ; 1 / 128 ; 1 / 256$ of MIC values. The 96-well micro-plate (NUNC, Danemark) containing $100 \mu \mathrm{L}$ of Mueller Hinton (MH) broth were used. For each bacteria strain, three columns of eight wells to the microplate were used. Each well has getting: the culture medium + combination of alkaloid compounds with Methicillin or Ampicillin + inoculum $(10 \mu \mathrm{l}$ of inocula) and INT $(50 \mu \mathrm{l}$;
$0.2 \mathrm{mg} / \mathrm{ml})$. The plates were covered and incubated at $37^{\circ}$ $\mathrm{C}$ for $24 \mathrm{~h}$. All tests were performed in triplicate and the bacterial activity was expressed as the mean of inhibitions produced. Inhibition of bacterial growth was judged by rose or yellow colour. The analysis of the combination of alkaloid compounds and Methicillin or Ampicillin was obtained by calculating the Fractional Inhibitory Concentration Index (FICI) as follows: FICI = (MIC of the combination of alkaloid compounds and Methicillin or Ampicillin/ $\mathrm{MICa}$ alone) + (MIC of the combination of alkaloid compounds and Methicillin or Ampicillin/MICb alone), where MICa (Minimal Inhibitory Concentration of alkaloid compounds from Cienfuegosia digitata cav.) and MICb (Minimal Inhibitory Concentration of Methicillin or Ampicillin). The FICI was interpreted as follows: (1) a synergistic effect when FICI $\leq 0.5$; (2) an additive or indifferent effect when FICI $>0.5$ and $<1$ and (3) an antagonistic effect when FICI $>1$. This study was carried out following [30] method with light modifications.

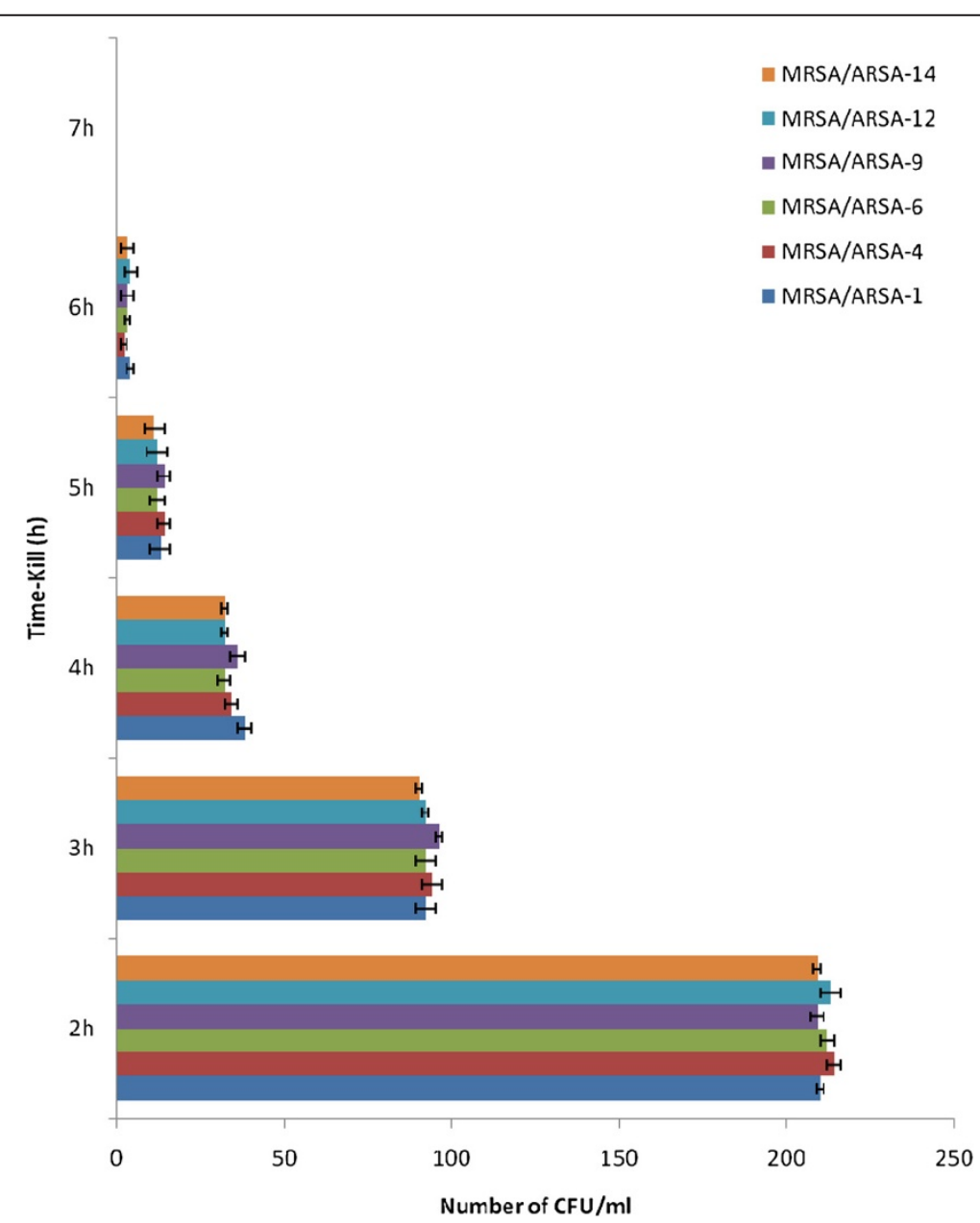

Figure 6 Viability of microorganisms after 6 hours exposure with Methicillin in combination and Alkaloid compounds from Cienfuegosia digitata Cav. Absence of colonies after 6 h. UFC uncountable before $2 \mathrm{~h}$. The results are the means of number of the colonies \pm standard deviations. 


\section{Results}

The present study reports the antibacterial potency of alkaloid compounds and conventional antibiotics. Alkaloid compounds and conventional antibiotics were tested for antibacterial activity against fifteen clinical isolates of Gram-positive bacteria (MRSA/ARSA) by disc diffusions, Minimum Inhibitory Concentration (MIC), Minimum bactericidal concentration (MBC), Time-kill assay and Fractional Inhibitory Concentration Index (FICI). One noticed that the susceptibility of the bacteria to the alkaloid compounds and in combination with conventional antibiotics on the basis of inhibition zone diameters varied according to microorganism, the results are reported in (Figures 1 and 2). There is a significant variation in the diameters of inhibition zone values (DIZ) of alkaloid compounds and their combination with conventional antibiotics. One noticed that all bacterial strains are resistant to the antibiotics comparatively to alkaloid compounds (Figures 1 and 2).

In the micro-well dilution assay (MIC) and Minimum bactericidal concentration (MBC) of alkaloid compounds and their combination with conventional antibiotics (Methicillin and Ampicillin), result varied according to microorganism (Figures 3 and 4). The MIC values were ranged from 12.5 to $50 \mu \mathrm{g} / \mathrm{ml}$ and as for the $\mathrm{MBC}$ values were ranged from 25 to $200 \mu \mathrm{g} / \mathrm{ml}$. The bactericidal and bacteriostatic effect of alkaloid compounds and their combination with conventional antibiotics was determined using the ratio $\mathrm{MBC} / \mathrm{MIC}$ (Table 1 ). Concerning the time-kill assay, the results showed that after $6 \mathrm{~h}$ exposition there was no viable microorganism in the initial inoculums (Figure 5, 6 and 7).

At last, with regard to FICI, our results indicate a synergistic effect between alkaloid compounds and the conventional antibacterial (Tables 2 and 3).

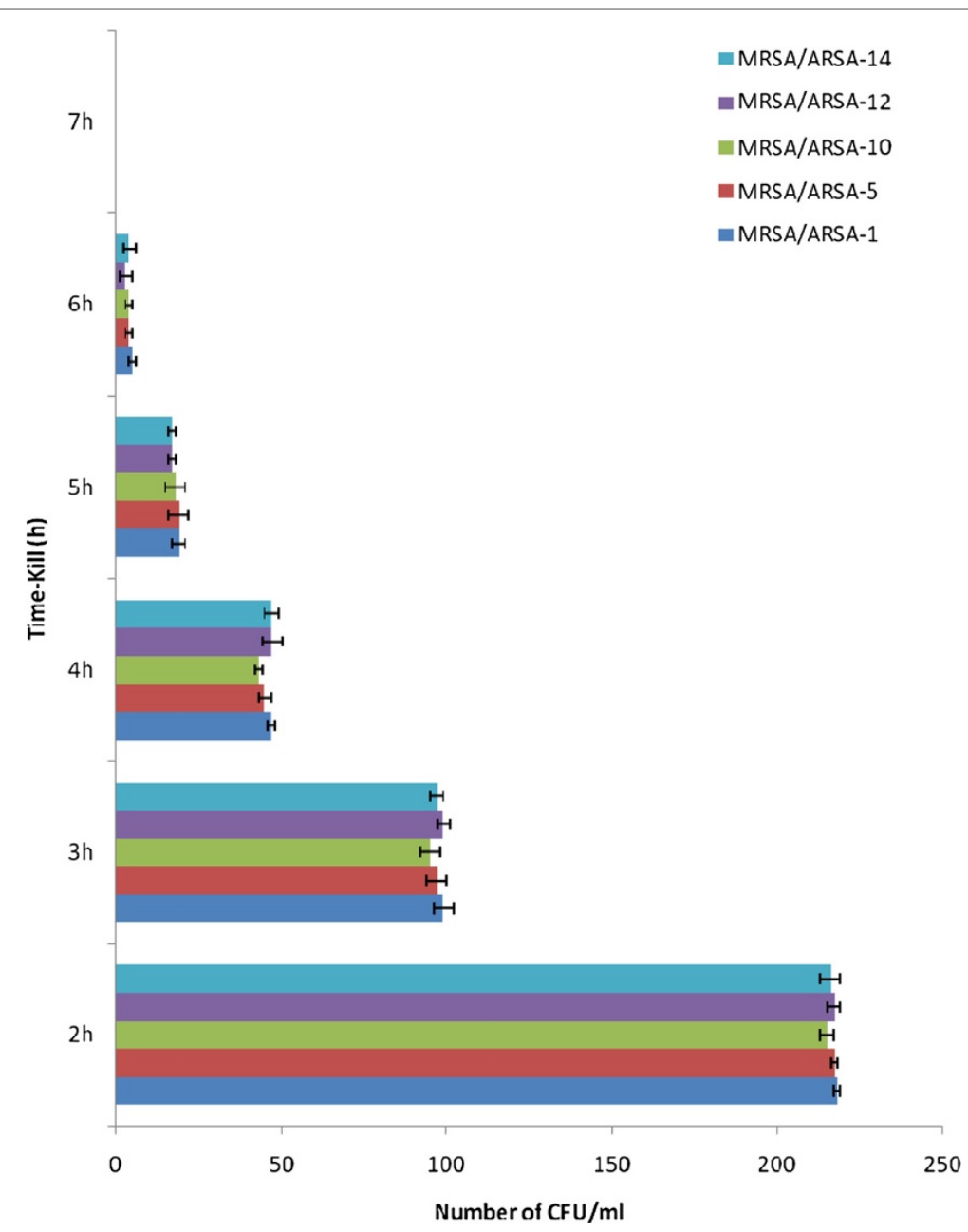

Figure 7 Viability of microorganisms after 6 hours exposure with Ampicillin in combination and Alkaloid compounds from Cienfuegosia digitata Cav. Absence of colonies after $6 \mathrm{~h}$. UFC uncountable before $2 \mathrm{~h}$. The results are the means of number of the colonies \pm standard deviations. 
Table 2 Fractional Inhibitory Concentration (FIC) and FICI of combination of Alkaloid compounds with Methicillin

\begin{tabular}{lccccc}
\hline Microorganisms & $\begin{array}{c}\text { MIC }(\boldsymbol{\mu g} / \mathbf{m l}) / \\
\text { Methicillin }\end{array}$ & FIC $_{\mathbf{a}}$ & FIC $_{\mathbf{b}}$ & $\mathbf{F I C l}$ & Effect \\
\hline MRSA/ARSA-1 & $>400$ & 0.50 & $\leq 0.03$ & $\leq 0.53$ & Synergistic \\
MRSA/ARSA-4 & $>400$ & 0.50 & $\leq 0.03$ & $\leq 0.53$ & Synergistic \\
MRSA/ARSA-6 & $>400$ & 0.25 & $\leq 0.03$ & $\leq 0.28$ & Synergistic \\
MRSA/ARSA-9 & $>400$ & 0.25 & $\leq 0.03$ & $\leq 0.28$ & Synergistic \\
MRSA/ARSA-12 & $>400$ & 0.5 & $\leq 0.03$ & $\leq 0.53$ & Synergistic \\
MRSA/ARSA-14 & $>400$ & 0.5 & $\leq 0.03$ & $\leq 0.53$ & Synergistic \\
\hline
\end{tabular}

$\mathbf{F I C}_{\mathbf{a}}=$ MIC of the combination/MICa alone; $\mathbf{F I C}_{\mathbf{b}}=$ MIC of the combination/ $\mathrm{MICb}$ alone and $\mathrm{FICl}=\mathrm{FIC}_{\mathrm{a}}+\mathrm{FIC}_{\mathrm{b}}$.

$a=$ Alkaloid fractions; $b=$ Methicillin.

The FICl was interpreted as follows: (1) a synergistic effect when $\mathrm{FICl} \leq 0.5$; (2) an additive or indifferent effect when $\mathrm{FICl}>0.5$ and $<1$ and (3) an antagonistic effect when $\mathrm{FICl}>1$.

\section{Discussion}

Today, there is a renewed interest in traditional medicine and an increasing demand for more drugs from plant sources. This revival of interest in plant-derived drugs is mainly due to the current widespread belief that green medicine is safe and more dependable than the costly synthetic drugs, many of which have adverse side effects [31]. In effect, herbal remedies used in folk medicine provide an interesting and still largely unexplored source for the creation and development of potentially new drugs for chemotherapy which might help overcome to growing problem of resistance and also the toxicity of the currently available commercial antibiotics [32]. There are a lot of antimicrobial drugs of which some are discovered or established and over 250,000 undiscovered flowering plants with medicinal properties exist in worldwide [33]. Hence, the last decade witnessed an increase in the investigations on plants as a source of human disease management [34] and more natural antimicrobials have driven scientists to investigate the effectiveness of inhibitory compounds such as extracts from plants [35].

Table 3 Fractional Inhibitory Concentration (FIC) and FICI of combination of Alkaloid compounds with Ampicillin

\begin{tabular}{lccccc}
\hline Microorganisms & $\begin{array}{l}\text { MIC }(\mu \mathrm{g} / \mathrm{ml}) / \\
\text { Ampicillin }\end{array}$ & $\mathrm{FIC}_{\mathrm{a}}$ & $\mathrm{FIC}_{\mathrm{b}}$ & $\mathrm{FICl}$ & Effect \\
\hline MRSA/ARSA-1 & $>400$ & 0.50 & $\leq 0.03$ & $\leq 0.53$ & Synergistic \\
MRSA/ARSA-5 & $>400$ & 0.50 & $\leq 0.03$ & $\leq 0.53$ & Synergistic \\
MRSA/ARSA-10 & $>400$ & 0.50 & $\leq 0.03$ & $\leq 0.53$ & Synergistic \\
MRSA/ARSA-12 & $>400$ & 0.50 & $\leq 0.03$ & $\leq 0.53$ & Synergistic \\
MRSA/ARSA-14 & $>400$ & 0.50 & $\leq 0.03$ & $\leq 0.53$ & Synergistic \\
\hline
\end{tabular}

$\mathbf{F I C}_{\mathbf{a}}=$ MIC of the combination/MICa alone; $\mathbf{F I C}_{\mathbf{b}}=$ MIC of the combination/ $\mathrm{MICb}$ alone and $\mathrm{FICl}=\mathrm{FIC}_{\mathrm{a}}+\mathrm{FIC}_{\mathrm{b}}$.

$a=$ Alkaloid fractions; $b=$ Ampicillin.

The $\mathrm{FICl}$ was interpreted as follows: (1) a synergistic effect when $\mathrm{FICl} \leq 0.5$;

(2) an additive or indifferent effect when $\mathrm{FICl}>0.5$ and $<1$ and (3) an

antagonistic effect when $\mathrm{FICl}>1$.
Phytochemical constituents such as tannins, flavonoids, alkaloids and several other aromatic compounds are secondary metabolites of plants that serve as defense mechanisms against predation by many microorganisms, insects and herbivores [36]. Several studies have been conducted on the antimicrobial activity of plant extracts found in folk medicine or isolated compounds such as alkaloids. Previous studies have showed that over compounds such as alkaloids have strong antimicrobial activities [17]. The report justifies the traditional use of Cienfuegosia digitata Cav. (Malvaceae) in the bacterial infections because of its capacity of alkaloids compounds [14].

The antimicrobial compounds from plants may inhibit microbial growth by different mechanisms than those generally indicate for antimicrobial agents and may have significant clinical value in the treatment of microbial resistance [37]. Thus, alkaloids activity could be attributed to their ability to intercalate DNA [38].

In generally, Gram-positive bacteria should be more susceptible since they have only an outer peptidoclycans layer which is not an effective permeability barrier as reported by [39]. But in this study, we found contradicting results. Staphylococcus aureus some Gram-positive has developed resistance to the $\beta$-lactam antibiotics due to the production of chromosomal or plasmid mediated $\beta$-lactamases or by producing penicillin binding proteins (PBPs). All the Staphylococcus aureus strains have from PBPs (PBP1 to PBP4), but MRSA express a special PBP (PBP2 or PBP2a) from the mec A gene PBP2a takes over the biosynthetic function of normal PBPs in the presence of inhibitory concentration of $\beta$-lactams because PBP2 has a decreased binding affinity to $\beta$-lactams [40]. This has resulted in the development of multidrug resistance against $\beta$-lactam and other antibiotics. In addition, the polysaccharide capsular material in some of the pathogenic microorganism is responsible for virulence and antimicrobial resistance [41]. This may also explain another aspect of bacterial resistance to conventional antibiotics. However one note that the alkaloid compounds or their combination with conventional antibiotics have effects on bacteria. This could be explained by the fact that the alkaloid compounds inhibit or destroy the action of $\beta$-lactamase.

Indeed, synergy research in phytomedicine has established itself as a new key activity in recent years. It is one main aim of this research to find a scientific rational for the therapeutic superiority of herbal drugs derived from traditional medicine as compared with single constituents thereof. Synergy effects of the mixture of bioactive constituents and their byproducts contained in plant extracts are claimed to be responsible for the improved effectiveness of many extracts and conventional antimicrobial drugs [28]. 


\section{Conclusion}

The results of present study supports the traditional usage of Cienfuegosia digitata Cav. (Malvaceae) and suggests that this herbaceous possess compounds with high antibacterial properties that can be used as antibacterial agents in developing new drugs for the therapy of infectious diseases caused by pathogenic bacteria. Moreover, based on the results of this study, alkaloid compounds of Cienfuegosia digitata Cav. (Malvaceae) should be analyzed further because of their potential as a source of broad spectrum antimicrobial compounds which can be use for treating infectious diseases caused by MRSA/ ARSA. This highlights the continuous interest in laboratory screening of medicinal plants, not only to determine the scientific rationale for their usage, but also to discover new active principles.

\section{Competing interests}

The authors declare that they have no competing interests.

\section{Authors' contributions}

KK carried out the study and wrote the manuscript, RRAS, ANL, JFM, AH and AS supervised the work and the manuscript. MHD and BMB contributed to the manuscript corrections. All authors read and approved the final manuscript.

\section{Acknowledgements}

The authors are grateful to the France Embassy in Burkina Faso/EGIDE-France for the mobility scholarship which has permitted to do this work. The authors think Prof. Millogo Rasolodimby from the plants Biology Department of the University of Ouagadougou for the botanically identified of plants.

\section{Author details \\ ${ }^{1}$ Laboratoire de Biochimie et Chimie Appliquées (LABIOCA), UFR/SVT, Université de Ouagadougou, Ouagadougou 0909 BP 848, Burkina Faso. ${ }^{2}$ Institut de Recherche en Ecologie Tropicale (IRET/CENAREST), BP:13354 Libreville, Gabon. ${ }^{3}$ Laboratoire de Phytopathologie, UFR Agrobiologie, Faculté des Sciences, Université des Sciences et Techniques de Masuku, Franceville, BP 943 Franceville, Gabon. ${ }^{4}$ Institut de Pharmacopée et de Médecine Traditionnelle (IPHAMETRA), Centre National de la Recherche Scientifique et Technologique (CENAREST), BP:1156 Libreville, Gabon. ${ }^{5}$ Laboratoire de Physiologie Animale, Electrophysiologie et de Pharmacologie, Faculté des Sciences, Université des Sciences et Techniques de Masuku, Franceville, Gabon. ${ }^{6}$ Laboratoire de Biochimie Alimentaire, Enzymologie, Biotechnologie et Bioinformatique, UFR/SVT, Université de Ouagadougou, 09 BP 848 Ouagadougou 09, Burkina Faso.}

Received: 16 March 2012 Accepted: 13 May 2012 Published: 20 June 2012

\section{References}

1. Sanches IS, Saraiva ZC, Tendeir TC, Serra JM, Dias DC, Delencastre H: Extensive intra-hospital spread of methicillin resistant Staphyloccocalclone. Int J Infect Disease 1998, 3:26-31.

2. Bachi BB, Rohrer S: Factors influencing methicillin resistance in Staphylococci. Arch. Microbiol. 2002, 178:165-171.

3. Hiramatsu K, Hamaki H, Ito T, Yabuta K, Ogura T, Tenova FC: Methicillin resistant Staphylococcus aureus clinical strains with reduced vomcomycin susceptibility. J Anti-Microbial Chemother 1997, 41:135-146.

4. Parekh J, Chanda S: In vitro antibacterial activity of the crude methanol extract of Woodfordia Fructicosa Kurz. Flower (Lythaceae) Braz. J. Microbiol. 2007, 38:204-207.

5. Dash BK, Sultana S, Sultana N: Antibacterial activities of methanol and acetone extracts of Ferrugreek (Trigonelle foenum) and Coriander (Coriandrum sativum). Life Sci Med Res 2011, 27:1-8.
6. Arya V, Yadav S, Kumar S, Yadav JP: Antimicrobial activity of Cassia occidentalis (Leaf) against various human pathogenic microbes. Life Sci Med Res 2010, 9:1-11.

7. Barbour EK, Al-Sharit M, Sagherian VK, Habe AN, Talhouk RS, Talkouk SN: Screening of select indigenous plants of Lebanon for antimicrobial activity. J Etnopharmacol 2004, 93:1-7.

8. Geyid A, Abebe D, Debella A, Makonnen Z, Aberra F: Screening of some medicinal plants of Ethiopia for their anti-microbial properties and chemical profiles. J Ethnopharmacol 2005, 97:421-427.

9. Rahman MS, Rahman MZ, Wahab MA, Chowdhury R, Rashid MA: Antimicrobial activity of some indigenous plants of Bangladesh. Dhaka Univ J Pharma Sci 2008, 7:23-26.

10. Elvin-Lewis M: Should we be concerned about herbal remedies. J. Ethnopharmacol. 2001, 75:141-164.

11. Silver $L$, Bostian K: Screening of natural products for antimicrobial agents. Eur. J. Clin. Microbiol. Infect. Dis. 1990, 9:455-461.

12. Ellof JN: Which extractant should be used for the screening and isolation of antimicrobial components from plants. J. Ethnopharmacol. 1998, 60:1-8.

13. Karim A, Nouman M, Munir S, Sattar S: Pharmacology and phytochemistry of Pakistani herbs and herbal drugs used for treatement of diabetes. Int J Pharmacol 2011, 7:419-439.

14. Nacoulma OG: Medicinal plants and their traditional uses in Burkina Faso. Ph.D. Thesis: University of Ouagadougou; 1996:328.

15. Konaté K, Souza A: Polyphenol Contents, Antioxidant and AntiInflammatory Activities of Six Malvaceae Species Traditionally used to treat Hepatitis B in Burkina Faso. Eur J Sci Res 2010, 44(4):570-580.

16. Le Minor L, Veron M: Bactériologie Médicale, eds Flammarion medecinesciences. 1984:773. ISBN 2-257-10418-8.

17. Karou D, Savadogo A, Canini A, Yameogo S, Montesano C, Simpore J, Colizzi V, Traore AS: Antibacterial activity of alkaloids from Sida acuta. Afr. J. Biotechnol. 2006, 5(2):195-200.

18. Perez C, Pauli M, Bazerque P: An antibiotic assay by the agar-well diffusion method. Acta Biologiae et Medecine Experimentalis 1990, 15:113-115.

19. Ezoubeiri A, Gadhi CA, Fdil N, Benharref A, Jana M, Vanhaelen M: Isolation and antimicrobial activity of two phenolic compounds from Pulicaria odora L. J. Ethnopharmacol. 2005, 99:287-292.

20. Pujol V, Villard J: Research of antifungal substances secreted by higher fungi in culture. French Pharmaceut J 1990, 48:17-22.

21. Rabe T, Mullholland D, Van Staden J: Isolation and identification of antibacterial compounds from Vernonia colorata leaves. J. Ethnopharmacol. 2002, 80:91-94.

22. NCCLS-National Committee for Clinical Laboratory Standards: Performance standard for anti-microbial susceptibilitytesting:eleventh informational supplement. Document M100-S11. Wayne, PA, USA: National Committee for Clinical Laboratory Standard; 2001.

23. Traoré R: Contribution has the Study of the Adhesion of Enterobacteries of the Kinds Klebsiella proteus and K serratia with the Human epithelial Cells. Doct thesis science pharmaceutical:: Université libre de Bruxelles; 1993:158.

24. Berche P, Gaillard JL, Simonet M: Nosocomial Infections Caused by Bacteria and Their Prevention in Bacteriology. Ed Flammarion Medicine Sciences 1988, :64-71.

25. Wolfe EF, Klepser ME, Pfaller MA: Antifungal dynamics of amphotericin B and fluconazole in combination against Candida albicans, effect of exposure time. Pharmacotherapy 1997, 17:189-189.

26. White RL, Bugess DS, Manduru M, Bosso JA: Comparison of three different in vitro methods of detecting synergy: Time-kill, chercherboard and $\mathrm{E}$ test. Antimicrob. Agents Chemother. 1996, 40:1914-1918.

27. National Committee for Clinical Laboratory Standards: Methods for Determining Bactericidal Activity of Antimicrobial Agent. Wayne, Pa: National Committee for Clinacal Laboratory Standards; 1992.

28. Rosato A, De Laurentis NVN, Armenise D, Millilo MA: Antibacterial effect of some essential oils administered alone or in combination with Norfloxacin. Phytomedicine 2007, 14:727-732.

29. Wolfe EF, Klepser ME, Pfaller MA: Antifungal dynamics of amphotericin B and fluconazole in combination against Candida albicans, effect of exposure time. Pharmacotherapy 1997, 17:189-189.

30. Williamson EM: Synergy and other interactions in phytomedicines. Phytomedicine 2001, 8:401-409. 
31. Agbafor KN, Akubuguo El, Ogbashi ME, Ajah PM, Ukwandu CC: Chemical and antimicrobial properties of leaf extracts of Zapoteca portoriceusis. Res J Med Plant 2011, 5:605-612.

32. Alam MT, Karim MM, Kham SN: Antibacterial activity of different organic extracts of Achyranthes aspera and Cassia alata. J Sci Res 2009, 1:393-398.

33. Madureira MDC: Rediscovering traditional medicine spore. 2008, 136:16-17.

34. Woldemichael GM, Wachter G, Singh MP, Maiese WM, Timmermann BN: Antibacterial diterpene from Calceolaria pinifolia. J Nat Prod 2003, 66:242-246.

35. Nasar-Abbas SM, Halkman AK: Antimicrobial effect of water extract of sumac (Rhus coriaria L.) on the growth of some food borne bacteria including pathogens. Int J Food Microbiol 2004, 97:63-69.

36. Doughari JH, Okafor NB: Antibacterial activity of Senna siamae leaf extracts on Salmonella typhi. Afr J Microbiol Res 2008, 2:42-46.

37. Ellof JN: Which extractant should be used for the screening and isolation of antimicrobial components from plants. J Ethnopharmacol 1998, 60:1-8.

38. Cowan MM: Plants products as antimicrobial agents. Clin Microbiol Rev 1999, 12:564-582.

39. Nostro A, Germano MP, D'Angelo V, Marino A, Cannatelli MA: Extraction methods and bioautography for evaluation of medicinal plant antimicrobial activity. Lett. Applied Microbial 2000, 30:379-384.

40. Bachi BB, Rothrer S: Factors influencing methicillin resistance in Staphylococci. Arch Microbiol 2002, 178:165-171.

41. Hooper DC: Emerging mechanisms of fluoroquinolone resistance. Emerg Infect Dis 2001, 7:337-341.

doi:10.1186/1476-0711-11-18

Cite this article as: Konate et al: Antibacterial activity against $\beta$ - lactamase producing Methicillin and Ampicillin-resistants Staphylococcus aureus: fractional Inhibitory Concentration Index (FICI) determination. Annals of Clinical Microbiology and Antimicrobials 2012 11:18.

\section{Submit your next manuscript to BioMed Central and take full advantage of:}

- Convenient online submission

- Thorough peer review

- No space constraints or color figure charges

- Immediate publication on acceptance

- Inclusion in PubMed, CAS, Scopus and Google Scholar

- Research which is freely available for redistribution 